\title{
Origins of High-Molecular-Weight Dissolved Organic Matter in the Middle Atlantic Bight: Clue from Lipids and Molecular $\delta^{13} \mathrm{C}$ Ratios
}

\author{
Li Zou ${ }^{1,2}$, Laodong Guo ${ }^{3}$, Baowei Sun ${ }^{4}$ and Ming-Yi Sun ${ }^{1,4, *}$
}

${ }^{l}$ Department of Marine Sciences, University of Georgia, Athens, GA 30602, USA; ${ }^{2}$ College of Environmental Science and Engineering, Ocean University of China, Qingdao, 266003, China; ${ }^{3}$ Department of Marine Science, University of Southern Mississippi, Stennis Space Center, MS, 39529, USA and ${ }^{4}$ College of Chemistry and Chemical Engineering, Ocean University of China, Qingdao, 266003, China

\begin{abstract}
Lipid compositions and compound-specific $\delta^{13} \mathrm{C}$ ratios of high-molecular-weight dissolved organic matter (HMW-DOM) in the Middle-Atlantic-Bight varied with water depth, implying that the origins of HMW-DOM at different layers of the ocean may differ.
\end{abstract}

\section{INTRODUCTION}

High-molecular-weight dissolved organic matter (HMWDOM, size between $1 \mathrm{kDa}$ and $0.2 \mu \mathrm{m}$ ), operationallydefined by ultrafiltration membrane cutoff, accounts for 20$35 \%$ of the total DOM in seawater [1,2]. This fraction of organic matter plays a more active role than low-molecularweight DOM in biogeochemical cycling of organic carbon and many important elements in ocean systems $[3,4]$. It has been suggested that the HMW-DOM throughout the ocean originates from the same source and has similar reaction histories [5,6]. However, other evidence showed that physical properties, chemical and isotopic compositions of HMWDOM varied with water depth [7-9]. In addition, DOM (including HMW-DOM) in surface waters has a much younger ${ }^{14} \mathrm{C}$ age compared to those in the middle and deep waters [10-12]. Depth-dependent variations in chemical and isotopic compositions of DOM imply that formation and cycling of HMW-DOM may differ through the water column, but few studies have addressed this issue. Although lipids in DOM pool account for a smaller fraction relative to other compounds such as carbohydrates and proteins, they have been used widely as more effective source biomarkers of $\mathrm{OM}$ in natural environments $[13,14]$.

The main objective of this study was to examine whether origins of HMW-DOM are variable with water depth by determining lipid distributions and compound-specific stable carbon isotopic compositions of the HMW-DOM samples, collected from the water column (three depths) in the Middle Atlantic Bight (MAB).

\section{EXPERIMENTAL}

\subsection{Sampling}

The HMW-DOM samples were collected from two sites in the Middle Atlantic Bight in July 1994: one near-shore station ( $30 \mathrm{~m}$ in depth; $75^{\circ} 10^{\prime} \mathrm{W}, 36^{\circ} 08^{\prime} \mathrm{N}$ ) and one off-shore station $\left(2,600 \mathrm{~m}\right.$ in depth; $\left.74^{\circ} 04^{\prime} \mathrm{W}, 36^{\circ} 09^{\prime} \mathrm{N}\right)$. One surface

*Address correspondence to this author at the Department of Marine Sciences, University of Georgia, Athens, GA 30602, USA;

E-mail:mysun@uga.edu
(2 m) HMW-DOM sample was colleted at the near-shore station and three samples at $2 \mathrm{~m}, 250 \mathrm{~m}$, and $2,550 \mathrm{~m}$ were respectively collected at the off-shore station using the crossflow ultrafiltration method [2]. Surface waters were directly pumped through a $0.2 \mu \mathrm{m}$ Nuclepore cartridge into a reservoir for ultrafiltration while subsurface and deep waters were collected by Niskin bottles in a CTD-Rosette system followed by filtration and ultrafiltration. The ultrafiltration system was equipped with Amicon S10N1 regenerated cellulose membranes $(1 \mathrm{kDa})$. The HMW-DOM in this study was operationally defined as the fraction from $1 \mathrm{kDa}$ to $0.2 \mu \mathrm{m}$, which represented $28-34 \%$ of the bulk DOC in our samples [2]. The isolated HMW-DOM was further desalted using dialfiltration with $20 \mathrm{~L}$ of Nanopure water [11]. The desalted HMW-DOM samples were freeze-dried and stored at $-24^{\circ} \mathrm{C}$ before chemical and isotopic analyses. Concentrations of DOC were measured by high temperature combustion method [2]. Carbon and nitrogen contents of HMW-DOM and their stable isotope compositions $\left(\delta^{13} \mathrm{C}\right.$ and $\left.\delta^{15} \mathrm{~N}\right)$ were measured by continuous flow isotope ratio mass spectrometry [9].

\subsection{Lipid Extraction and Analysis}

Freeze-dried HMW-DOM samples $(\sim 20-70 \mathrm{mg})$ were extracted with organic solvents: $10 \mathrm{ml}$ methanol followed by $3 \times 10 \mathrm{ml}$ methylene chloride-methanol $(2: 1, \mathrm{v} / \mathrm{v})$. This extract was defined as free lipids (solvent extractable). The free lipid extracts were then saponified with $0.5 \mathrm{M} \mathrm{KOH}$ in metha$\mathrm{nol} / \mathrm{H}_{2} \mathrm{O}(95: 5, \mathrm{v} / \mathrm{v})$ at $100^{\circ} \mathrm{C}$ for $2 \mathrm{hrs}$. The neutral lipids were first extracted from the solution with hexane under $\mathrm{pH} \sim 13$ and the acidic lipids were subsequently extracted after acidification $(\mathrm{pH}<2)$. The extracted residues of HMWDOM samples were further saponified and the neutral and acidic lipids were separately extracted under different $\mathrm{pH}$ conditions. These lipids were defined as bound lipids (residue-saponification-released). Fatty acids in both free and bound pools were methylated with $12 \% \mathrm{BF}_{3}$-methanol at $100^{\circ} \mathrm{C}$ for $2 \mathrm{hrs}$ to form fatty acid methyl esters (FAMEs), while neutral lipids in both pools were treated with BSTFA [ $\mathrm{N}, \mathrm{O}$-bis (trimethylsilyl)trifluoroacetamide] in acetonitrile to form TMS-ethers. 
The FAMEs and TMS-ethers in both extract pools were quantified by capillary gas chromatography using a HewlettPackard $6890 \mathrm{GC}$ with an on-column injector and a flame ionization detector. Prior to GC analysis, a known amount of internal standard was added into each extract sample to aid quantification (nonadecanoic acid methyl ester for acidic lipids and $5 \alpha$-cholestane for neutral lipids). Separations of FAMEs and TMS-ethers were achieved with a $30 \mathrm{~m} \times 0.25$ $\mathrm{mm}$ i.d. HP-5 column. Identification of FAMEs and TMSethers was performed on a Shimadzu QP-5000 gas chromatograph-mass spectrometry system.

\subsection{Compound-Specific Isotope Analysis}

Compound-specific stable carbon isotopic ratios were measured using a Varian 3400 GC-combustion system interfaced with an isotope ratio mass spectrometer (IRMS, Finnigan MAT 252). Peaks eluting from the GC column (DB-5, $\mathrm{J} \& \mathrm{~W}$ Scientific) were combusted to $\mathrm{CO}_{2}$ over $\mathrm{CuO} / \mathrm{Pt}$ wires at $850^{\circ} \mathrm{C}$ and on-line transported to the IRMS. The isotopic composition of $\mathrm{CO}_{2}$ peaks was measured by the IRMS operated at $10 \mathrm{kV}$ acceleration potential and by magnetic sector mass separation. The $\delta^{13} \mathrm{C}$ ratios were calibrated with a reference $\mathrm{CO}_{2}$ gas and reported in parts per mil (\%o) relative to the PDB standard. The standard deviation of IRMS analysis was approximately $\pm 0.7 \%$ o based on internal standard measurements $(n=8)$. To obtain actual compound isotope ratios, the $\delta^{13} \mathrm{C}$ of FAMEs and TMS-ethers were corrected for the carbon atoms added during derivatization, based on the bulk $\delta^{13} \mathrm{C}$ ratios of reagents.

\section{RESULTS AND DISCUSSION}

Concentrations of total DOC and HMW-DOC, C/N ratios, and isotope ratios varied differently through the water depth in the Middle Atlantic Bight (Table 1). Generally, concentrations of total DOC and HMW-DOC in the surface water (two sites) were higher ( 2X) than those in the subsurface and deep waters. The HMW-DOC comprised 34\% of the bulk DOC in surface waters and $28 \%$ in deep waters. The depth distribution pattern of the HMW-DOM is similar to those observed in other ocean areas $[1,2]$. The $\mathrm{C} / \mathrm{N}$ ratios of HMW-DOM varied similarly to those of bulk DOM [15] in the Middle Atlantic Bight, with lower values in surface waters compared to those in deep waters. However, in Sargasso Sea (open Atlantic Ocean), the $\mathrm{C} / \mathrm{N}$ ratios remained almost invariant with water depth [5]. Difference in the $\mathrm{C} / \mathrm{N}$ ratio of HMW-DOM at the surface and deep waters of the MAB may reflect complexity of OM sources in the continental shelf area. Although the HMW-DOM stable isotopes $\left(\delta^{13} \mathrm{C}\right.$ and $\left.\delta^{15} \mathrm{~N}\right)$ varied within a small range $(\sim 1 \%$ o $)$ throughout the water column, their radioisotope ratios $\left(\Delta^{14} \mathrm{C}\right)$ were distinctly different between surface and subsurface/deep waters [11]. ${ }^{14} \mathrm{C}$ age of the HMW-DOM in the surface water was much younger $(<1,000 \mathrm{yr})$ compared to those in the subsurface/deep waters $(\sim 4,000 \mathrm{yr})$. Coincidently, ${ }^{14} \mathrm{C}$ ages of total DOM and POM in the Middle Atlantic Bight varied with water depth in the same way as the HMW-DOM [16].

Total lipid concentrations (including 15 fatty acids and 2 fatty alcohols, normalized to HMW-DOC) in the HMWDOM samples varied with water depth in the Middle Atlantic Bight (Fig. 1). The concentrations in the surface waters from two sites (near-shore and off-shore) were similar but were $4-5 \mathrm{X}$ higher than those in the subsurface/deep waters. Within the total lipid pool, free lipids were dominant $(>80$ $90 \%$ ) over bound lipids. Previous studies $[5,8]$ have shown that concentrations and yields of total carbohydrates in HMW-DOM decreased remarkably from surface waters to subsurface/deep waters, which is attributed to rapid remineralization in the upper water column. However, nitrogen components (e.g., amino acids) in HMW-DOM were found to be much less variable with depth, which suggests that cycling dynamics for different components of HMW-DOM may be independent [5].

While the concentrations of total lipids decreased markedly from surface water to subsurface/deep waters (Fig. 1), the relative compositions of lipids varied differently with depth in free and bound pools (Fig. 2). For example, the relative compositions of free fatty acids (e.g., saturated to unsaturated ratio) had little change throughout the water column while the relative proportions of free fatty alcohols varied noticeably between the surface and subsurface/deep waters (Fig. 2a). In the bound pool, the ratios of saturated to unsaturated fatty acids decreased from surface $(\sim 3)$ to subsurface/deep waters (1.3-1.6) and fatty alcohols disappeared in subsurface/deep waters (Fig. 2b). With deceasing in proportions of some saturated and monounsaturated fatty acids (e.g., 14:0 and 16:0, 16:1), the bacteria-specific fatty acids such as iso- and anteiso-15:0 and 17:0, and 18:1(n7) increased their proportions in deep waters. Many previous studies [17-19] have demonstrated that fatty acids are a dominant lipid component in marine POM, DOM, and colloidal OM. Their relative compositions in these OM pools varied with primary production, microbial activity, and environmental conditions.

Table 1. Sampling Information, Concentrations of DOC and HMW-DOC in Seawater, and Bulk Measurements of the HMWDOM Samples. Data of Radiocarbon and DOC are from [11]

\begin{tabular}{|c|c|c|c|c|c|c|c|c|}
\hline $\begin{array}{l}\text { Sample } \\
\text { ID }\end{array}$ & $\begin{array}{c}\text { Sampling Depth } \\
\text { (Water Depth) }\end{array}$ & $\begin{array}{l}\text { DOC } \\
(\mu \mathrm{M})\end{array}$ & $\begin{array}{c}\text { HMW-DOC } \\
(\mu \mathrm{M})\end{array}$ & $\mathrm{C} / \mathrm{N}$ & $\begin{array}{l}\delta^{13} \mathrm{C} \\
(\% o)\end{array}$ & $\begin{array}{l}\delta^{15} \mathrm{~N} \\
(\% o)\end{array}$ & $\begin{array}{r}\Delta^{14} \mathbf{C} \\
(\% \%)\end{array}$ & $\begin{array}{l}{ }^{14} \mathrm{C} \text { Age } \\
(\mathrm{yr} \text { BP })\end{array}$ \\
\hline $10-S$ & $2 \mathrm{~m}(30 \mathrm{~m})$ & 98 & 33 & 13 & -22.1 & 6.61 & $-89 \pm 5$ & $751 \pm 47$ \\
\hline $13-\mathrm{S}$ & $2 \mathrm{~m}(2600 \mathrm{~m})$ & 82 & 28 & 11 & -21.2 & 5.06 & $-110 \pm 5$ & $935 \pm 51$ \\
\hline $13-\mathrm{M}$ & $250 \mathrm{~m}(2600 \mathrm{~m})$ & 54 & 16 & - & -22.5 & 5.27 & $-399 \pm 4$ & $4091 \pm 56$ \\
\hline
\end{tabular}




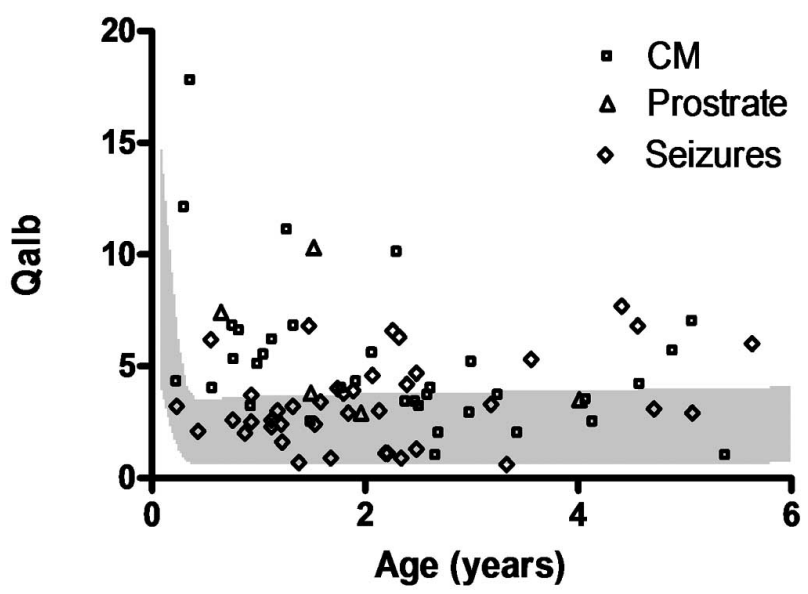

Fig. (1). Concentrations of total lipids (free and bound) in HMW-DOM samples collected from the Middle Atlantic Bight (stations: 10S, 2 m; 13S, 2 m; 13M, $250 \mathrm{~m}$; 13D, $2550 \mathrm{~m})$.
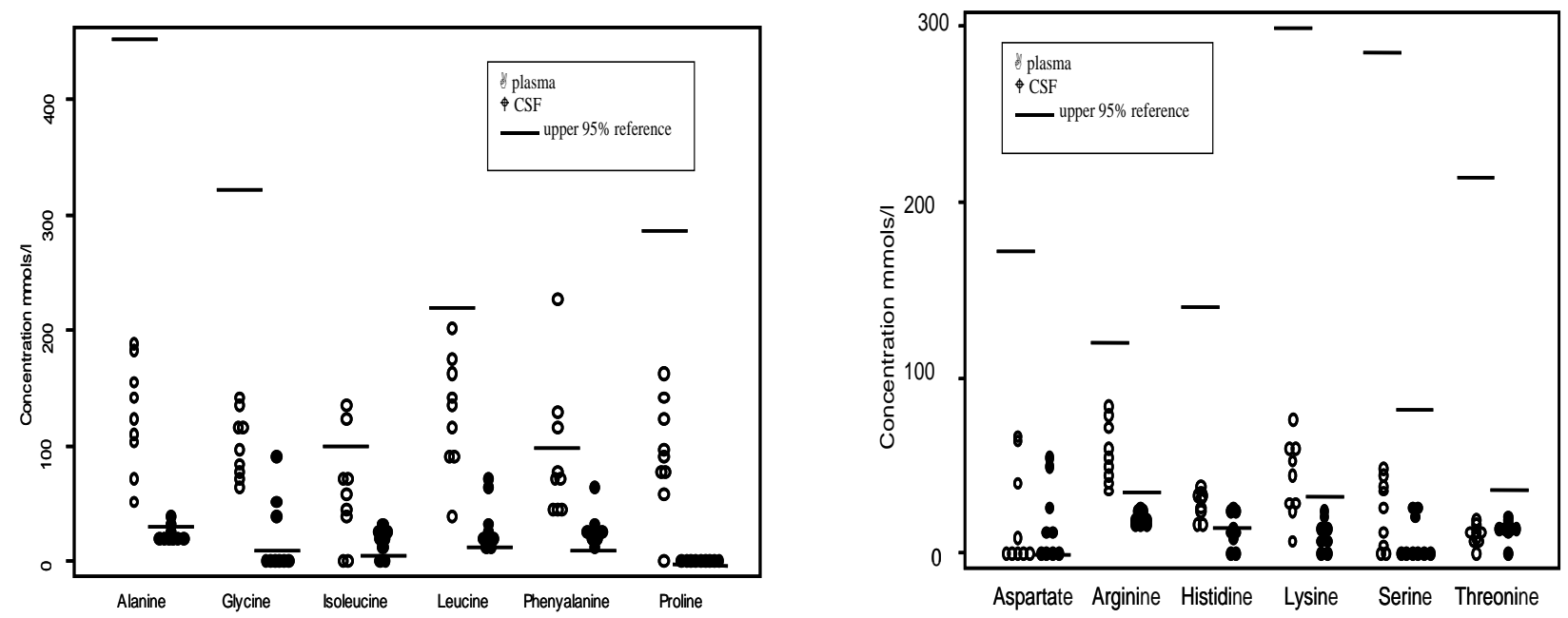

Fig. (2). Relative compositions of fatty acids and fatty alcohols in (a) free pool and (b) bound pool.

$\delta^{13} \mathrm{C}$ ratios of major lipid components in the HMW-DOM were different from compound to compound (Fig. 3). For example, there was a 7-8\%o difference in $\delta^{13} \mathrm{C}$ between 16:0 and 16:1 fatty acids while the difference between two fatty alcohols (12:0 and 18:0) was 3-4\%o throughout the water column. It is known that 16:0 fatty acid is a non-specific compound from almost all organic carbon source while 16:1 fatty acid is predominantly contributed by algal and bacterial sources $[13,20] . \delta^{13} \mathrm{C}$ ratios of $16: 0$ fatty acid in the surface waters from two sampling sites differed significantly, implying variable contributions of organic carbon from multiple sources between near-shore and off-shore stations. Consistent $\delta^{13} \mathrm{C}$ ratios of $16: 1$ fatty acid in the surface waters between two sites indicated a similarly combined algalbacterial source. It is interesting to note that $\delta^{13} \mathrm{C}$ ratios of all major lipid compounds (including bacteria-specific branched fatty acids) shift negatively (depletion) from surface to sub- surface/deep waters (Fig. 3). This $\delta^{13} \mathrm{C}$ depletion pattern of lipid compounds with depth is somewhat inconsistent with the almost constant $\delta^{13} \mathrm{C}$ ratios of total HMW-DOM through the water column (Table 1). Different depth variation patterns in $\delta^{13} \mathrm{C}$ ratio between total carbon pool and individual lipids suggest that origins (or formation pathways) of HMWDOM may vary with depths. It is likely that the relatively constant $\delta^{13} \mathrm{C}$ ratios of total carbon pool result from a net balance of different components with varying isotopic compositions at different depths while variable compoundspecific $\delta^{13} \mathrm{C}$ ratios more clearly reflect different OC sources.

Although lipids account for a small fraction of OC in HMW-DOM, their distributions provide a more clear indication for carbon sources and formation pathways compared to other less specific components [21]. Especially, combination of lipid biomarker approach with compound-specific $\delta^{13} \mathrm{C}$ measurement further enhances the applications of molecular 


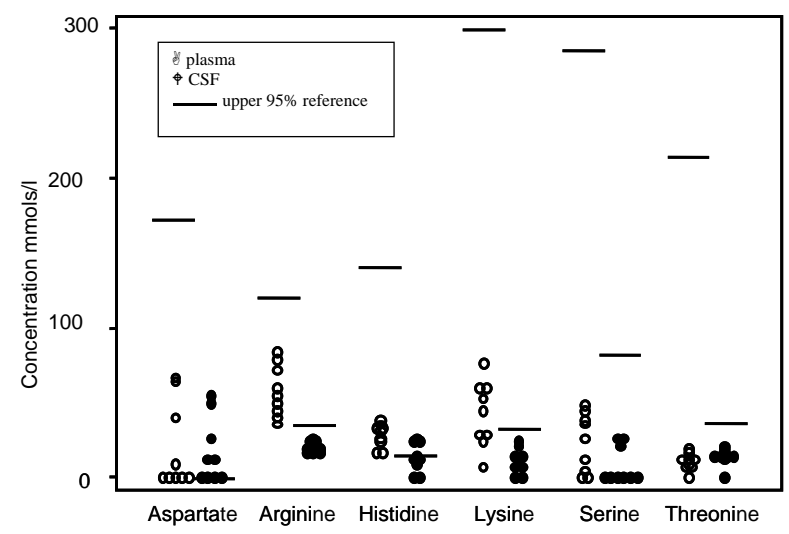

Fig. (3). $\delta^{13} \mathrm{C}$ ratios of major lipid molecules though the water column of Middle Atlantic Bight (open symbols: station 13; closed symbols: station 10 surface).

tracers in tracing biogeochemical cycling of various OC pools [22]. One previous study [14] revealed that the lipids in HMW-DOM samples, which were collected from surface waters in several estuarine and coastal areas, were derived presumably from two sources: reworked phytoplankton materials and released bacterial membrane components. In this study, fatty acid compositions (absences of long-chain saturated and polyunsaturated fatty acids) and their $\delta^{13} \mathrm{C}$ ratios of HMW-DOM samples, collected from MAB surface waters, were similar to those of the surface water samples [14]. Thus, we conclude that the surface water HMW-DOM associated lipids in the MAB is also derived predominately from phytoplankton and bacterial sources. However, different lipid contents and compositions and especially their depleted $\delta^{13} \mathrm{C}$ ratios in the subsurface and deep water samples indicate that HMW-DOM in these waters may derive from other sources.

In general, HMW-DOM can be formed through two major pathways: (1) incorporation of low-molecular-weight dissolved organic matter by adsorption, condensation, humification, and abiotical aggregation [23-25]; and (2) disaggregation of large particulate organic matter by biophysical and biochemical processes [26,27]. Based on the ages of HMWDOM samples collected from different depths (Table 1), it seems that the HMW-DOM in surface water is formed mainly through the 2nd pathway because its young age is more close to POM rather than LMW-DOM $[11,16,28]$. On the other hand, the ages of HMW-DOM samples in subsurface and deep waters are similar to those of LMW-DOM and much older than those of large sinking POM $[11,29]$. Therefore, we infer that the HMW-DOM in subsurface/deep waters is formed not by disaggregation of large sinking particles.

There are several possibilities for the formation of HMW-DOM in subsurface and deep waters, different from that in surface water. First, small size $(<0.5 \mu \mathrm{m})$ particles from atmospheric deposition, which have a more negative $\delta^{13} \mathrm{C}$ ratio with a terrestrial origin [30], may be a potential source for HMW-DOM at subsurface/deeper waters. One study [31] indicated that the $\delta^{13} \mathrm{C}$ ratios of ultrafiltrated POC decreased (depletion) significantly below the mixed layers in open-ocean water column, partly due to the contribution of the smaller particles from atmosphere. Second, terrestrial plant-derived HMW-DOM (with more negative $\delta^{13} \mathrm{C}$ ) may be transported along benthic nephloid layer (BNL) into deepocean. There is evidence showing that the MAB is a dynamic ocean margin, which serves as a significant contributor of coastal sediment-derived DOC to the deep ocean through BNL [32]. Meanwhile, some well-degraded marine organic matter in shallow water sediments may be resuspended and transported along the BNL, partially contributing to HMW-DOM [33]. Third, dissolved humic substances may serve as a more important source for HMW-DOM in deep water than in surface waters. Some studies $[34,35]$ have shown that humic substances are more abundant in deep waters than in surface waters.

Our conclusion that the origins of HMW-DOM may vary with water depths is supported by other findings. For example, stoichiometric (C:N, C:P, and N:P) ratios in DOM pool were found to increase with depth [15]. This pattern of increasing ratios with depth is partly attributed to preferential decomposition of $\mathrm{N}$ and $\mathrm{P}$ components relative to $\mathrm{C}$. However, a huge difference in DOM ages ( $>$ a few thousands) between surface and deep waters suggests that deep water DOM pool is not simply derived from decomposed OC from the overlying surface water. One study [34] demonstrated the presence of at least two compositionally distinct components in HMW-DOM pool: acyl polysaccharide (APS) and humic substances. The former is a dominant component of HMWDOM in surface waters while the latter is more abundant in deep waters. Benner and Biddanda [36] conducted an interesting experiment to examine photochemical transformations of surface and deep seawater DOM and found that exposure of surface water DOM to sunlight resulted in a $75 \%$ reduction in bacterial production whereas exposure of deep water DOM caused a $40 \%$ enhancement in bacterial production. Their results imply that chemical compositions of DOM are very different between surface and deep waters. Since our data are limited in one geographic site, more studies at other ocean sites are needed to further confirm the variable origins of HMW-DOM through the water column.

\section{ACKNOWLEDGMENTS}

We thank the crew and officers of the R/V Gyre and all individuals involved in sample collection during the 94G4 cruise. This work was supported in part by the U.S. National 
Science Foundation (grants: OCE-0526111 to MYS and OCE-0627820 to LDG) and the Ocean University of China .

\section{REFERENCES}

[1] Benner R, Pakulski JD, McCarthy M, et al. Bulk chemical characteristics of dissolved organic matter in the ocean. Science 1992; $255: 1561-1564$.

[2] Guo LD, Santschi PH, Warnken K. Dynamics of dissolved organic carbon (DOC) in oceanic environments. Limnol Oceanogr 1995; 40: 1392-1403.

[3] Amon RMW, Benner R. Rapid cycling of high-molecular-weight organic matter in the ocean. Nature 1994 ; 369: 549-552.

[4] Guo LD, Santschi PH. Composition and cycling of colloids in marine environments. Rev Geophys 1997 ; 35: 17-40.

[5] McCarthy M, Hedges JI, Benner R. Major biochemical composition of dissolved high molecular weight organic matter in seawater. Mar Chem 1996; 55: 281-297.

[6] Repeta DJ, Quan TM, Aluwihare LI, et al. Chemical characterization of high molecular weight dissolved organic matter in fresh and marine waters. Geochim Cosmochim Acta 2002 ; 66: 955-962.

[7] Coble PG. Characterization of marine and terrestrial DOM in seawater using excitation-emission matrix spectroscopy. Mar Chem 1996; 51: 325-346.

[8] Skoog A, Benner R. Aldoses in various size fractions of marine organic matter: Implications for carbon cycling. Limnol Oceanogr 1997 ; 42: 1803-1813

[9] Guo LD, Tanaka N, Schell DM, et al. Nitrogen and carbon isotopic composition of high-molecular-weight dissolved organic matter in marine environments. Mar Ecol Prog Ser 2003; 252, 51-60.

[10] Druffel ERM, Williams PM, Bauer JE, et al. Cycling of dissolved and particulate organic matter in the open ocean. J Geophys Res 1992 ; 97: 15639-15659.

[11] Guo LD, Santschi PH, Cifuentes LA, et al. Cycling of high molecular weight dissolved organic matter in the Middle Atlantic Bight as revealed by carbon isotopic $\left({ }^{13} \mathrm{C}\right.$ and $\left.{ }^{14} \mathrm{C}\right)$ signatures. Limnol Oceanogr 1996; 41: 1242-1252.

[12] Bauer JE, Druffel ERM. Ocean margins as a significant source of organic matter to the deep ocean. Nature 1998; $392: 482-485$.

[13] Volkman JK, Barrett SM, Blackburn SIB, et al. Microalgal biomarkers: A review of recent research developments. Org Geochem $1998 ; 29: 1163-1179$.

[14] Zou L, Wang XC, Callahan J, et al. Bacterial roles in the formation of high-molecular-weight dissolved organic matter in estuarine and coastal waters: Evidence from lipids and the compound-specific isotopic ratios. Limnol Oceanogr 2004; 49: 297-302.

[15] Hopkinson CS, Fry JB, Nolin AL. Stoichiometry of dissolved organic matter dynamics on the continental shelf of the northeastern U.S.A. Continent Shelf Res 1997; 17: 473-489.

[16] Bauer JE, Druffel ERM, Wolgastc DM, et al. Temporal and regional variability in sources and cycling of DOC and POC in the northwest Atlantic continental shelf and slope. Deep-Sea Res II 2002; 49: 4387-4419.

[17] Parrish CC. Dissolved and particulate marine lipid classes: a review. Mar Chem 1988; 23: 17-40.

[18] Derieux S, Fillaux J, Saliot A. Lipid class and fatty acid distributions in particulate and dissolved fractions in the north Adriatic sea. Org Geochem 1998; 29: 1609-1621.
[19] Liu QJ, Parrish CC, Helleur R. Lipid class and carbohydrate concentrations in marine colloids. Mar Chem 1998; 60: 177-188.

[20] Cranwell PA. Lipids of aquatic sediments and sedimenting particulates. Prog Lipid Res 1982; 21: 271-308.

[21] Mannino A, Harvey HR. Lipid composition in particulate and dissolved organic matter in the Delaware Estuary: Sources and diagenetic patterns. Geochim Cosmochim Acta 1999 ; 63: 22192235

[22] Zou L, Sun MY, Guo LD. Temporal variations of organic carbon inputs into the upper Yukon River: Evidence from fatty acids and their stable carbon isotopic compositions in dissolved, colloidal and particulate phases. Org Geochem 2006; 37: 944-956.

[23] Opsahl S, Benner R. Distribution and cycling of terrigenous dissolved organic matter in the ocean. Nature 1997; 386: 480-482.

[24] Chin WC, Orellana MV, Verdugo P. Spontaneous assembly of marine dissolved organic matter into polymer gels, Nature 1998; 391: 568-572.

[25] Kerner M, Hohenberg H, Ertl S, et al. Self-organization of dissolved organic matter to micelle-like microparticles in river water. Nature 2003; 422: 150-154.

[26] Wang WX, Guo LD. Production of colloidal organic carbon and trace metals by phytoplankton decomposition. Limnol Oceanogr 2001; 46: 278-286.

[27] Rochelle-Newall EJ, Fisher TR. Production of chromophoric dissolved organic matter fluorescence in marine and estuarine environments: an investigation into the role of phytoplankton. Mar Chem $2002 ; 77: 7-21$

[28] Loh AN, Bauer JE, Druffel ERM. Variable ageing and storage of dissolved organic components in the open ocean. Nature 2004; 430: 877-880

[29] Wang XC, Druffel ERM, Lee C. Radiocarbon in organic compound classes in particulate organic matter and sediment in the deep Northeast Pacific Ocean. Geophys Res Lett 1996; 23: 3583-3586.

[30] Chesselet R, Fontugne M, Baut-Menard P, et al. The origin of particulate organic carbon in the marine atmosphere as indicated by its stable carbon isotopic composition. Geophys Res Lett $1981 ; 8$ : 345-348.

[31] Benner R, Biddanda B, Black B, et al. Abundance, size distribution, and stable carbon and nitrogen isotopic compositions of marine organic matter isolated by tangential-flow ultrafitration. Mar Chem 1997 ; 57: 243-266.

[32] Mitra S, Bianchi TS, Guo LD, et al. Terrestrially derived dissolved organic matter in the Chesapeake Bay and the Middle Atlantic Bight. Geochim Cosmochim Acta 2000; 64: 3547-3557.

[33] Guo LD, Santschi PH. Sedimentary sources of old high molecular weight dissolved organic carbon from the ocean margin benthic nepheloid layer. Geochim Cosmochim Acta 2000; 64: 651-660.

[34] Aluwihare LI, Repeta DJ, Chen RF. Chemical composition and cycling of dissolved organic matter in the Mid-Atlantic Bight Deep-Sea Res II 2002; 49: 4421-4437.

[35] Engbrodt R, Kattner G. On the biogeochemistry of dissolved carbohydrates in the Greenland Sea (Arctic). Org Geochem 2005; 36 : 937-948

[36] Benner R, Biddanda B. Photochemical transformations of surface and deep marine dissolved organic matter: Effects on bacterial growth. Limnol Oceanogr 1998; 43: 1373-1378. 